\title{
Pendampingan Masyarakat Dalam Upaya Pengembangan Sentra Produksi Jagung Hibrida di Desa Morome, Kabupaten Konawe Selatan, Sulawesi Tenggara
}

\section{(Mentoring of Community in the Effort of Developing Hybrid Corn Production Centers in Morome Village, Konawe Selatan District, Southeast Sulawesi)}

\author{
Lely Okmawaty Anwar', Sri Fatma Sari' ${ }^{1}$, Mustam$^{2}$, Latifa Fekri ${ }^{3 *}$ \\ 1 Program Studi teknologi hasil Perikanan, Fakultas Perikanan dan Ilmu Kelautan, Universitas Muhammadiyah Kendari, \\ Jl. K.H. Muhammad Dahlan No.10, Wowawanggu, Kadia, Kota Kendari, Sulawesi Tenggara 93127. \\ 2 Program Studi Manajemen, Fakultas Ekonomi dan Bisnis Islam, Universitas Muhammadiyah Kendari, \\ Jl. K.H. Muhammad Dahlan No.10, Wowawanggu, Kadia, Kota Kendari, Sulawesi Tenggara 93127. \\ 3 Program Studi Manajemen Sumber Daya Perairan, Fakultas Perikanan dan Ilmu Kelautan, Universitas Halu Oleo \\ Jl. H.E.A. Mokodompit, Anduonohu, Kambu, Kota Kendari, Sulawesi Tenggara 93232. \\ *Penulis Korespondensi: latifafekrirasyid@gmail.com \\ Diterima September 2019/Disetujui Agustus 2020
}

\begin{abstract}
ABSTRAK
Tujuan pendampingan masyarakat ini adalah untuk meningkatkan perekonomian masyarakat Desa Morome melalui peningkatan produksi jagung hibrida. Pelaksanaan dilakukan dengan metode sistem Pengelolaan Tanaman Terpadu (PTT), yaitu pendekatan inovatif dan dinamis dalam upaya meningkatkan produksi dan pendapatan petani melalui perakitan komponen teknologi secara partisipatif bersama petani. Hasil pendampingan menujukkan peningkatan hasil produksi tanam jagung hibrida pipil kering $4.250 \mathrm{~kg} / \mathrm{ha}$ dengan nilai RC Rasio 2, dengan keuntungan senilai Rp 6.905.000/ha. PTT sangat dianjurkan untuk terus diterapkan di semua areal tanaman jagung sebagai upaya pengembangan produksi jagung hibrida.
\end{abstract}

Kata kunci: Desa Morome, jagung hibrida, pendampingan

\begin{abstract}
The aim of assistance is to improve the economy of the Morome Village community by increasing the production of hybrid maize. Implementation is carried out using the Integrated Crop Management (PTT) system method, which is an innovative and dynamic approach in an effort to increase production and farmer income through participatory assembly of technology components with farmers. The results of the assistance showed an increase in the production of dry-shelled hybrid maize $4,250 \mathrm{~kg} /$ hectare with an RC ratio of 2, with a profit of IDR 6,905,000/hectare. Integrated crop management is highly recommended to continue to be applied in all maize areas as an effort to develop hybrid maize production.
\end{abstract}

Keywords: assistance, hybrid corn, Morome Village

\section{PENDAHULUAN}

Jagung merupakan salah satu tanaman pangan tropis dan komoditas pertanian yang penting setelah padi. Selain sebagai bahan pangan, jagung memiliki peran sebagai bahan farmasi, dan pakan ternak baik biji maupun tongkolnya (Kabumaini \& Tjetjep 2010). Selanjutnya Rusono et al. (2014) menyatakan bahwa perkembangan permintaan jagung domestik mengalami peningkatan setiap tahunnya.

Produksi tanaman jagung di Sulawesi Tenggara di tahun 2019 mencapai 279.170 ton
(BPS Provinsi Sulawei Tenggara 2020). Luas produksi tanaman jagung di Kabupaten Konawe Selatan tahun 2019 sebesar 46.035 ton dengan luas panen 10.895 ha, untuk produktivitasnya mencapai 42.25 kw/ha (BPS Kabupaten Konawe Selatan 2020). Indonesia menargetkan, produksi 30 juta ton jagung pada tahun 2018 atau penanaman jagung seluas 3 juta ha agar impor jagung dapat dihentikan (Balitsereal 2017). Salah satu upaya untuk mewujudkannya dan menjadi bagian dari pencapaian target tersebut maka pemerintah Sulawesi Tenggara melalui Dinas Tanaman Pangan dan Peternakan mem- 
programkan Sulawesi Tenggara sebagai sentra pengembangan dan produksi tanaman jagung di Indonesia yang dimulai pada tahun 2017. Hal tersebut didasarkan pada hasil kajian BPTP Sultra (2014) yang melaporkan produktivitas jagung hibrida pipil kering dapat mencapai lebih dari 5 ton/ha. Dukungan pemerintah akan program tersebut ditandai dengan penanaman perdana jagung hibrida yang dilakukan langsung oleh Menteri Pertanian Indonesia di Konawe Utara pada tanggal 15 Januari 2017 dan perluasan areal tanam serta penggunaan benih hibrida. Pemerintah terus berupaya mengenalkan benih jagung hibrida kepada petani dan mengharapkan petani di Indonesia menggunakan benih tersebut agar produksi jagung nasional dapat meningkat guna memenuhi permintaan pasar. Hasil kajian Direktorat Pembenihan Tanaman Pangan (DPTP) tahun 2010 melaporkan bahwa produktivitas jagung hibrida lebih tinggi dibandingkan jagung komposit dan lokal.

Desa Morome adalah salah satu desa di Kecamatan Konda Kabupaten Konawe Selatan Provinsi Sulawesi Tenggara. Luas wilayahnya \pm $15 \mathrm{~km}^{2}$ dan jumlah penduduk sekitar 1500 jiwa (BPS Kabupaten Konawe Selatan 2015). Masyarakat Desa Morome sebagian besar berasal dari pulau Jawa (masyarakat transmigrasi) sejak tahun 1973. Sebagai desa hasil pemekaran, Morome mulai berkembang pada tahun 2011. Desa Morome berjarak $\pm 30 \mathrm{~km}$ dari Kota Kendari dan $\pm 70 \mathrm{~km}$ dari pusat pemerintahan Kabupaten Konawe Selatan di Andoolo. Akses jalan yang memadai sehingga dapat ditempuh melalui jalur darat dengan berbagai kendaraan. Selain menggarap lahan tanaman jagung, masyarakat transmigrasi dari pulau Jawa memanfaatkan lahan kosong untuk menanam tanaman holtikultura seperti sayuran hijau cabai serta berternak ayam, kambing, dan sapi. Tufaila et al. (2014) melaporkan bahwa jenis tanah wilayah Kecamatan Konda termasuk Desa Morome berupa endapan aluvial tua sehingga berpotensi dikembangkan sebagai lahan pertanian.

Permintaan akan produk peternakan khususnya unggas terus meningkat setiap tahun sehingga memicu laju permintaan jagung sebagai pakan utamanya. Ketersediaan pakan merupakan hal yang penting dalam segi produksi ternak karena menjadi faktor utama dalam usaha peternakan, serta memberi kontribusi sebesar 70-80\% dari keseluruhan biaya produksi. Berdasarkan peluang tersebut, masyarakat Desa Morome memanfaatkan lahan yang belum tergarap untuk menanam jagung hibrida. Ketersediaan lahan masyarakat yang luas, fasilitas dan kemudahan yang diberikan oleh pemerintah, menjadikan Desa Morome dapat dikembangkan sebagai desa sentra produksi jagung hibrida. Selain bermata pencaharian sebagai petani, masyarakat Desa Morome memiliki hewan ternak seperti ayam (pedaging maupun petelur), sapi maupun kambing. Limbah (kotoran) dari peternakan jumlahnya cukup melimpah namun tidak termanfaatkan oleh masyarakat setempat. Limbah tersebut dapat diolah lebih lanjut menjadi pupuk organik mengingat permintaan akan pupuk organik saat ini melonjak pesat seiring dengan keluarnya aturan pemerintah menaikkan Harga Eceran Tertinggi (HET) bagi pupuk kimia bersubsidi sehingga beberapa daerah produksi pupuk organik ikut meningkat.

Pupuk organik memiliki keunggulan yang tidak dimiliki oleh pupuk anorganik, selain sebagai penyubur juga mampu sebagai pembenah tanah, tidak memicu timbulnya efek rumah kaca, dan dapat diaplikasikan pada semua jenis tanah dengan kemampuan meluruh nutrien bertahap, sehingga dapat dikelola oleh industri kecil. Keunggulan lainnya adalah kandungan nutrien yang tidak kalah dengan pupuk anorganik, biaya murah, dan bahan baku yang tersedia melimpah. Dengan demikian tujuan program pengembangan desa mitra adalah meningkatkan perekonomian masyarakat Desa Morome melalui peningkatan produksi pertanian jagung hibrida dalam bentuk pendampingan yang difasilitasi oleh tim pengusul sebagai fasilitator yang berasal dari perguruan tinggi. Kegiatan ini diharapkan mampu meningkatkan produksi jagung hibrida di Kabupaten Konawe Selatan, Sulawesi Tenggara.

\section{METODE PELAKSANAAN KEGIATAN}

\section{Waktu dan Tempat}

Kegiatan telah dilaksanakan selama 6 bulan, yaitu pada bulan April-September 2019. Lokasi kegiatan pengabdian di Desa Morome, Kecamatan Konda, Kabupaten Konawe Selatan, Provinsi Sulawesi Tenggara. Dua kelompok tani binaan adalah Attaina Hisbah dan Al Hikmah.

\section{Metode Pelaksanaan}

Mekanisme pelaksanaan kegiatan terdiri dari diskusi informal, persiapan lahan, penanaman, 
pembuatan sumber pengairan teknis, dan pengadaan peralatan/mesin produksi.

\section{- Diskusi informal}

Kegiatan pendahuluan sebagai langkah awal pelaksanaan program ini adalah melakukan diskusi informal antara tim fasilitator dari perguruan tinggi, anggota mitra dan beberapa warga setempat dengan Penyuluh Pertanian Lapangan (PPL) wilayah tugas di kecamatan Konda (Gambar 1).

\section{- Persiapan lahan}

Tahap persiapan lahan dilakukan dengan sistem Olah Tanah Sempurna (OTS) karena kondisi tanah yang cenderung kering. Tanah diolah menggunakan bajak yang ditarik oleh traktor, dan disisir hingga rata (Gambar 2). Lahan yang dijadikan lokasi untuk percontohan pertanian jagung hibrida luasnya kurang lebih 2 ha. Selanjutnya pembuatan drainase dilakukan untuk pengaliran air yang berlebih dari areal pertanaman, terutama saat musim hujan karena tanaman jagung peka terhadap kelebihan air. Saluran drainase dibuat pada saat penyiangan pertama menggunakan alat cangkul. Saluran drainase berfungsi sebagai penampung air saat

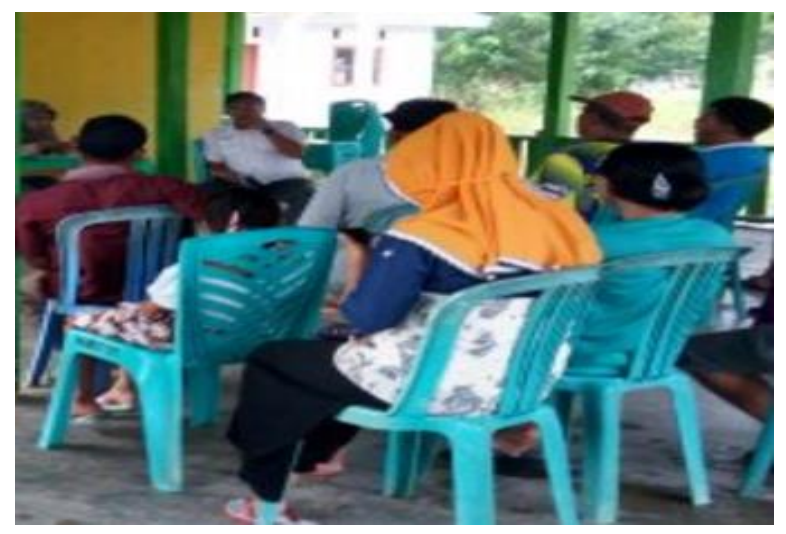

Gambar 1 Proses diskusi informal antara tim fasilitator, mitra, dan petugas lapangan.

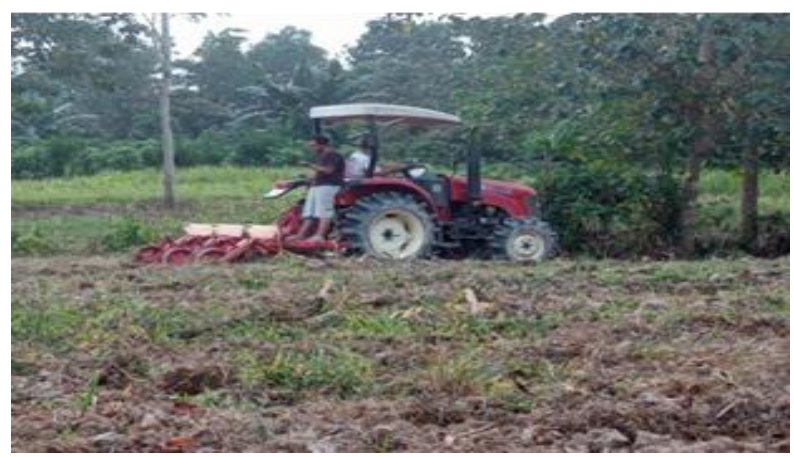

Gambar 2 Proses pengolahan lahan menggunakan bajak yang ditarik oleh traktor. air berlebih atau saat musim hujan. Setelah itu dilakukan pemberian bahan organik berupa pupuk organik yaitu limbah dari peternakan masyarakat setempat tujuannya memperbaiki kesuburan fisik, kimia, maupun biologi tanah.

\section{- Penanaman}

Proses penanaman dilakukan setelah tahap persiapan lahan selesai. Berdasarkan panduan umum Pengelolaan Tanaman Terpadu (PTT) jagung menurut kementrian pertanian tahun 2016, bibit yang digunakan adalah jenis varietas unggul hibrida yang berlabel yaitu P21 merek Pioneer dan NK7328 Sumo merek Syngenta (Gambar 3). Dasar pemilihan bibit adalah memiliki tingkat kemurnian dan daya tumbuh yang tinggi (> 95\%) dan umumnya ditemukan pada benih yang berlabel. Populasi tanaman ditentukan oleh jarak tanam dan mutu benih yang digunakan.

\section{- Pembuatan sumber pengairan teknis}

Pada sistem pengairan lahan, masyarakat mitra pada umumnya bergantung pada intensitas hujan, yaitu sistem tadah hujan sehingga sumber pengairan masih sangat terbatas. Kondisi ini menyebabkan produktivitas hasil pertanian belum dapat maksimal. Oleh karena itu, untuk menyelesaikan persoalan mitra yang berkaitan dengan ketersediaan air di lahan pertanian maka dibangunlah sumber pengairan berupa sumur air artesis, wadah penampungan dan pipa-pipa saluran untuk mengalirkan air ke seluruh area penanaman (Gambar 4), dengan harapan kegiatan penanaman tetap dapat dilakukan pada saat musim kemarau.

\section{- Pengadaan peralatan/mesin produksi}

Selama ini masyarakat Desa Morome melaksanakan kegiatan pertanian jagung secara manual, mulai dari pengolahan lahan, penanaman, pembedengan, pemanenan hingga

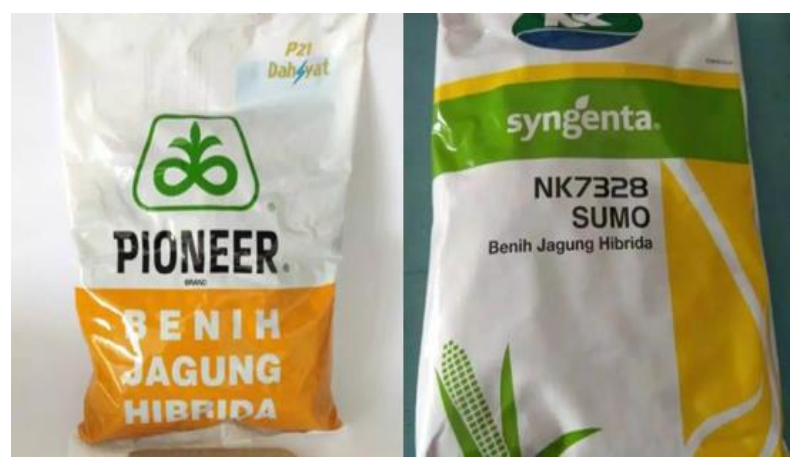

Gambar 3 Jenis bibit varietas hibrida unggul yang digunakan. 
pengupasan kulit jagung. Oleh karena itu membutuhkan tenaga, waktu dan biaya yang besar sehingga dianggap tidak efektif dan efisien. Berdasarkan permasalahan tersebut, maka diperlukan penyelesaian guna meningkatkan produktivitas kegiatan pertanian jagung melalui pengadaan peralatan atau mesin produksi yang tepat guna, sehingga target menjadikan Desa Morome sebagai sentra jagung ternak organik segera dapat terwujud. Beberapa mesin produksi yang dianggap tepat guna dan diperlukan oleh mitra guna mendorong produktivitas usaha pertanian dan berhasil diadakan pada program ini adalah mesin pemanen, mesin pengupas kulit jagung dan mesin penggembur tanah (Gambar 5). Pengadaan mesin tersebut dinilai tepat karena mampu digunakan dengan baik oleh tim mitra selama berkegiatan.

\section{HASIL DAN PEMBAHASAN}

Materi diskusi antara lain pemberian informasi dan edukasi berupa teori terkait kondisi tanah mitra yang akan ditempati untuk melakukan penanaman jagung, teknik praktis dalam meremajakan dan mempersiapkan lahan tanam, proses pemupukan menggunakan pupuk organik, rekomendasi bibit yang tepat, jarak

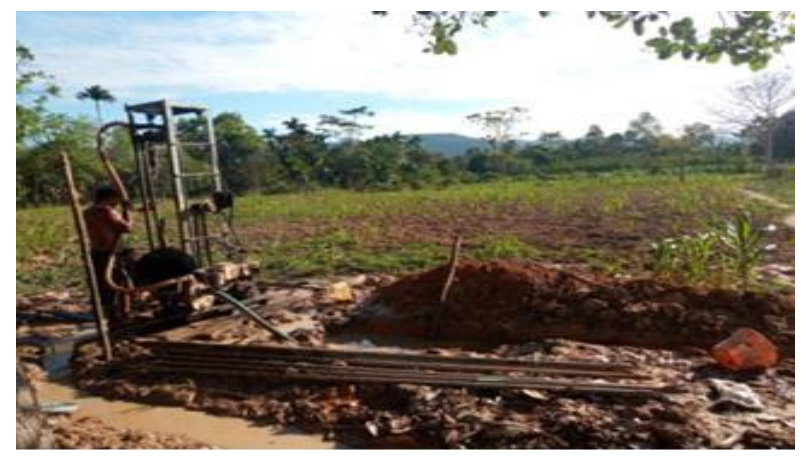

Gambar 4 Proses pembuatan irigasi teknis di lahan pertanian.

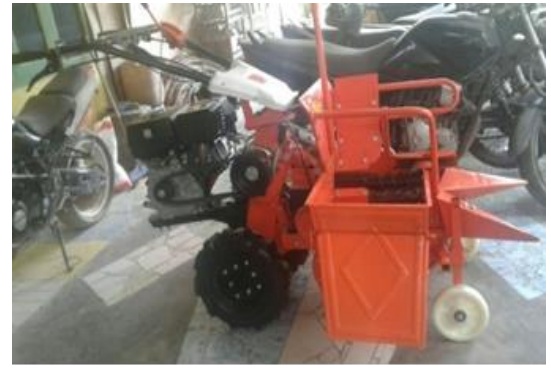

a

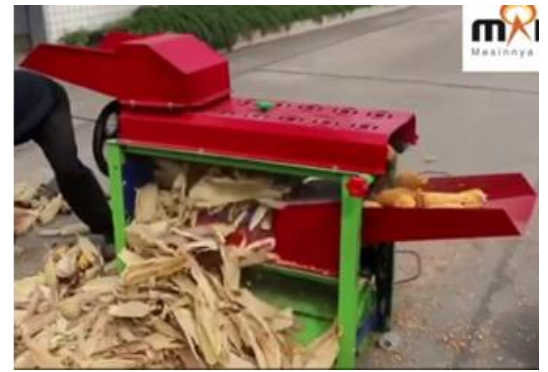

b tanam, proses pemeliharaan terutama penggunaan pembasmi rumput termasuk dari jenis dan dosisnya, teknis pengairan serta target pemanenan. Diskusi informal antar tim fasilitator dari perguruan tinggi dengan anggota mitra dilakukan secara intensif tiga kali seminggu dengan kisaran jumlah peserta 10-15 orang/ pertemuan. Diskusi informal antar tim fasilitator dari perguruan tinggi, anggota mitra dan warga dilakukan 1 kali sebulan dengan kisaran jumlah peserta 15-18 orang/pertemuan. Diskusi informal antar tim fasilitator dari perguruan tinggi, anggota mitra, warga dan penyuluh Pertanian Lapangan (PPL) wilayah tugas di Kecamatan Konda dilakukan 1 kali sebulan yang dihadiri 18-20 orang/pertemuan. Prosesi diskusi berjalan dengan baik dan memberikan dampak positif.

Kondisi tanah mitra untuk tanaman jagung memerlukan tambahan pupuk. Hal ini berdasarkan hasil penelitian Raharjo et al. (2013) yang melaporkan bahwa status hara/kebutuhan pupuk di daerah Konda termasuk di dalamnya Desa Morome untuk tanaman jagung membutuhkan tambahan unsur N sebanyak $300 \mathrm{~kg} / \mathrm{ha}$, P sebanyak $175 \mathrm{~kg} / \mathrm{ha}$, dan K sebanyak $50 \mathrm{~kg} / \mathrm{ha}$ dengan nilai pH 4,5. Selanjutnya Sutejo (1992) menyatakan bahwa informasi terkait riwayat lahan mitra juga penting diketahui demi kesuksesan target yang ingin dicapai. Berdasarkan penelitian Busanello et al. (2015) juga menjelaskan bahwa adanya interaksi genotipe $\mathrm{x}$ lingkungan pada tanaman jagung yang berpengaruh signifikan terhadap karakter hasil dan bobot tongkol jagung.

Proses peremajaan dan persiapan lahan tanam diawali dengan pemberian pupuk organik. Pupuk organik yang digunakan adalah kotoran ayam yang dicampur dengan sekam padi (perbandingan 1:1), pupuk digunakan sebanyak $2.400 \mathrm{~kg} / \mathrm{ha} / 125$ hari atau pada 1 periode tanam (125 hari). Setelah 20 dan 40 hari penanaman

Gambar 5 Mesin produksi untuk peningkatan produktivitas, a) mesin panen, b) mesin pengupas, dan c) mesin penggembur. 
dilanjutkan dengan pemupukan menggunakan pupuk urean dan ponska, masing-masing 200 $\mathrm{kg} / \mathrm{ha}$.

Pengendalian gulma, menggunakan 3 jenis produk, yaitu: 1) Herbisida jenis Rambo Gold yang digunakan sebelum penanaman; 2) Herbisida selektif jenis Kayabas, yang digunakan setelah 10 hari penanaman; dan 3) Herbisida jenis Noxon Mix yang digunakan setelah 50 hari penanaman. Penggunaan masing-masing herbisida dicampur dengan air dengan perbandingan 1:180.

Komponen teknologi yang diterapkan dalam Pengelolaan Tanaman Terpadu (PTT) dikelompokkan ke dalam teknologi dasar dan pilihan. Komponen teknologi PTT sangat dianjurkan untuk diterapkan di semua areal pertanaman jagung. Sebelum kegiatan pengabdian dilaksanakan kegiatan penanaman jagung telah dilakukan sebanyak 2 kali periode dan selama kegiatan nilai RC rasio 0,96 dengan hasil panen pipil kering $950 \mathrm{~kg} / \mathrm{ha}$ sehingga hasil panen hanya menutupi biaya produksi. Selama ini masyarakat mengandalkan tanaman sampingan jangka pendek sebagai pemasukan tambahan. Hasil pengabdian menujukkan peningkatan hasil produksi tanam masyarakat dengan nilai RC rasio 2, hasil panen $4.250 \mathrm{~kg} / \mathrm{ha}$ dengan keuntungan senilai Rp 6.905.000/ha. Hal ini sesuai dengan tujuan kegiatan yang didasari oleh pemilihan bibit dengan daya tumbuh yang tinggi ( $>95 \%$ ) dan jarak tanam 70-75 x $20 \mathrm{~cm} \mathrm{(1}$ biji per lubang) atau 70-75 x $40 \mathrm{~cm}$ (2 biji per lubang). Secara rinci komponen teknologi yang diterapkan kepada mitra di Desa Morome tersaji pada Tabel 1.

Persiapan lahan yang dilakukan dengan sistem Olah Tanah Sempurna (OTS) karena kondisi tanah yang cenderung kering sangat sesuai diterapkan khususnya di Desa Morome.

Tabel 1 Penerapan komponen teknologi pada pelaksanaan penanaman jagung hibrida di Desa Morome

\begin{tabular}{|c|c|}
\hline \multicolumn{2}{|c|}{ Komponen dasar } \\
\hline Aspek & Implementasi \\
\hline $\begin{array}{l}\text { Varietas unggul } \\
\text { hibrida }\end{array}$ & $\begin{array}{l}\text { Pioneer } 21 \text { dan Syngenta } \\
\text { NK7328 SUMO }\end{array}$ \\
\hline $\begin{array}{l}\text { Benih bermutu dan } \\
\text { berlabel }\end{array}$ & $\begin{array}{l}\text { Berlabel dan memiliki } \\
\text { daya tumbuh tinggi, yaitu } \\
>95 \%\end{array}$ \\
\hline $\begin{array}{l}\text { Populasi } 66.000- \\
75.000 \text { tanaman/ha }\end{array}$ & $\begin{array}{l}\text { Jarak tanam } 70-75 \times 20 \\
\mathrm{~cm}(1 \text { biji per lubang) } \\
\text { atau } 70-75 \times 40 \mathrm{~cm}(2 \mathrm{biji} \\
\text { per lubang) }\end{array}$ \\
\hline $\begin{array}{l}\text { Pemupukan dilakukan } \\
\text { berdasarkan } \\
\text { kebutuhan dan status } \\
\text { hara tanah }\end{array}$ & $\begin{array}{l}\text { Setelah } 20 \text { hari dan } 40 \\
\text { hari penanaman dilan- } \\
\text { jutkan dengan pemupu- } \\
\text { kan menggunakan pupuk } \\
\text { urean dan ponska, } \\
\text { masing-masing } \\
\text { 200kg/ha. }\end{array}$ \\
\hline
\end{tabular}

Pembuatan saluran irigasi teknis

Pemberian bahan organik

Pembumbunan Pengendalian gulma

Panen tepat waktu dan pengeringan segera
Komponen pilihan

Olah Tanah Sempurna (OTS) pada

lahan kering. Tanah diolah dengan bajak ditarik traktor, lalu digaru dan disisir hingga rata

Sumber air dari penggalian sumur bor. Air dialirkan ke lahan menggunakan pipa dengan sistem gravitasi dari bak penampungan. Air dikontrol karena jagung peka terhadap kelebihan air

Pemberian pupuk organik yaitu kotoran ayam dicampur sekam padi dengan perbandingan 1:1

Menggunakan alat manual

1. Herbisida jenis Rambo Gold, digunakan sebelum penanaman;

2. Herbisida selektif jenis Kayabas, digunakan setelah 10 hari penanaman;

3. Herbisida jenis Noxon Mix, digunakan setelah 50 hari penanaman. Penggunaan masing-masing herbisida dicampur dengan air dengan perbandingan 1:180.

Panen dilakukan jika kelobot sudah mengering, atau berwarna cokelat, biji telah mengeras, dan terbentuk lapisan hitam minimal 50\% pada setiap baris biji. pemipilan setelah kadar air 20\% lalu dijemur kembali hingga kadar air 15\%. 
Hal ini ditinjau dengan hasil produksi yang meningkat. Kondisi lahan sebelum dan setelah diolah menggunakan traktor terlihat pada Gambar 6. Balitsereal (2006); Sirappa \& Razak (2010) menyatakan bahwa kondisi lahan yang buruk akan berpengaruh terhadap rendahnya produktivitas hasil tanam, oleh sebab itu pengolahan tanah sangat dianjurkan sebelum proses penanaman.

Berdasarkan hasil pendampingan kelompok tani di lokasi kegiatan memperlihatkan bahwa jarak tanam yang dianjurkan adalah 70-75 x 20 cm (1 biji per lubang) atau 70-75 x $40 \mathrm{~cm}$ (2 biji per lubang). Jarak tanam sangat dibutuhkan bagi tanaman, hal ini berkaitan dengan intensitas cahaya yang diperoleh untuk mendukung pertumbuhannya. Jarak tanam berpengaruh terhadap persaingan antar tanaman dalam mendapatkan air dan unsur hara (Purwono \& Hartono 2005; Mayadewi \& Ari 2007). Selanjutnya Irawan et al. (2019) menyatakan bahwa perlakuan jarak tanam menunjukkan adanya pengaruh nyata terhadap pertumbuhan dan hasil produksi tanaman jagung. Menurut Mimbar \& Saubari (1990), dengan meningkatnya kerapatan maka penetrasi cahaya matahari ke dalam tajuk akan berkurang, akibatnya proses fotosintesis menurun, sehingga dengan sendirinya akan mengurangi ukuran tongkol. Hasil penanaman dapat dilihat pada Gambar 7.

Pembangunan sumber pengairan berupa sumur air artesis di lokasi penanaman jagung adalah solusi yang baik dalam penyelesaian persoalan mitra yang berkaitan dengan ketersediaan air di lahan pertanian mereka yang sangat kering. Penelitian menunjukkan hasil panen pipil kering $>4$ ton/ha. Menurut Aqil et al. (2007), jagung merupakan tanaman dengan tingkat penggunaan air sedang, berkisar antara 400-500 mm/musim. Selanjutnya Aqil et al. (2007) melaporkan bahwa dengan irigasi yang tepat waktu dan jumlah tepat, maka diharapkan akan didapatkan hasil pipil jagung 3-7 ton/ha.

Pengadaan mesin produksi yang tepat guna dinilai tepat karena mampu digunakan dengan baik oleh tim mitra selama kegiatan dan Desa Morome sebagai sentra jagung ternak organik segera dapat terwujud. Habib (2013) menyatakan bahwa ketersediaan mesin adalah salah satu faktor yang berpengaruh terhadap produksi jagung.

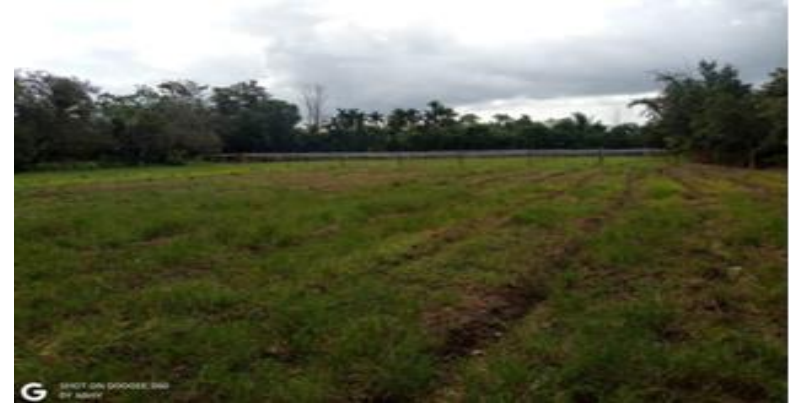

a

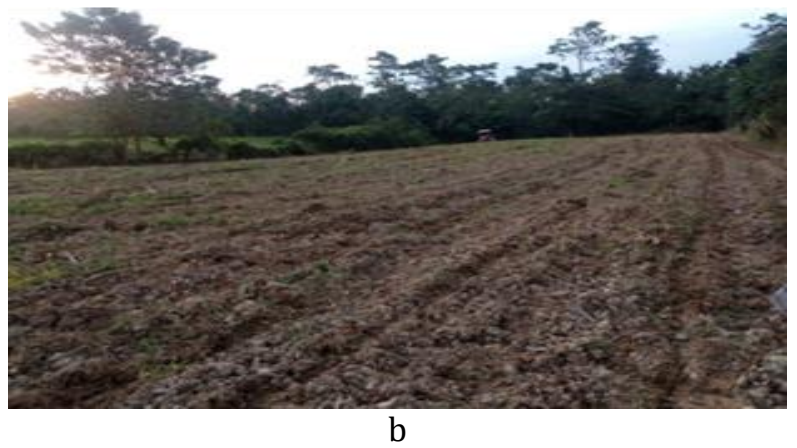

Gambar 6 a) Kondisi lahan sebelum diolah menggunakan traktor, dan b) Kondisi lahan setelah diolah menggunakan traktor

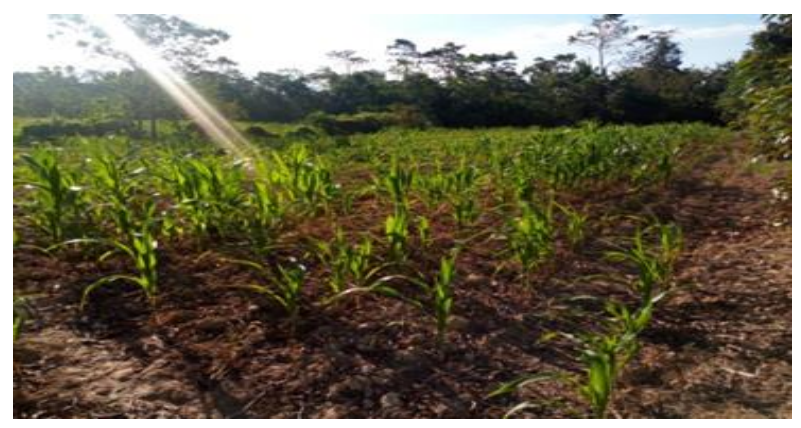

Gambar 7 Tanaman jagung yang tumbuh setelah penanaman.

\section{SIMPULAN}

Kegiatan pendampingan mampu meningkatkan produktivitas hasil panen jagung hibrida dalam upaya mendukung Desa Morome sebagai sentra produksi jagung hibrida. Penguatan pemasaran perlu didukung oleh pemerintah setempat dengan harga beli yang sesuai.

\section{UCAPAN TERIMAKASIH}

Kami mengucapkan terima kasih kepada Kementrian Riset, Teknologi, dan Pendidikan 
Tinggi atas bantuan dana melalui hibah pengabdian tahun 2018/2019

\section{DAFTAR PUSTAKA}

Aqil M, Firmansyah IU, Akil M. 2007. Pengelolaan Air Tanaman Jagung. Maros (ID): Balai Penelitian Tanaman Serealia. Page: 219-237.

[BPS] Badan Pusat Statistik Kabupaten Konawe Selatan. 2015. Kabupaten Konawe Selatan Dalam Angka. BPS Kabupaten Konawe Selatan.

[BPS] Badan Pusat Statistik Kabupaten Konawe Selatan. 2020. Kabupaten Konawe Selatan Dalam Angka. BPS Kabupaten Konawe Selatan.

[BPS] Badan Pusat Statistik Provinsi Sulawesi Tenggara. 2020. Kabupaten Konawe Selatan Dalam Angka. BPS Provinsi Sulawesi Tenggara

[BPTP] Badan Penelitian dan Pengembangan Pertanian Sulawesi Tenggara. 2014. Rekomendasi varietas, waktu tanam dan cara tanam serta pemupukan pada tanaman padi, jagung, dan kedelai (pajele) Provinsi Sulawesi Tengara. Kendari (ID): Kementrian Pertanian.

Balitsereal. 2006. Deliniasi Percepatan Pengembangan Teknologi PTT Jagung pada Beberapa Agroekosistem. Bahan Padu Padan Puslitbangtan dengan BPTP. Bogor (ID): Balitsereal Maros, 13-14 Maret 2006. 14 hal.

Balitsereal. 2017. Laporan Kinerja Balai Penelitian Tanaman Serealia Tahun 2017. Maros (ID): Badan Litbang Kementrian Pertanian Maros.

Busanello C, Queiróz de Souza V, Costa de Oliveira A, Nardino M, Beretta D, Caron BO, Schmidt D, Freitas de Oliveira V, Konflaz VA. 2015. Adaptability and Stability of Corn Hybrids in Southern Brazilian Environments. Agricultural Science. 7(9): 228-235. https://doi.org/ 10.5539/jas.v7n9p228

Habib A. 2013. Analisis faktor-faktor yang memengaruhi produksi jagung. Agrium. 18(1): 79-87.
Irawan S, Safruddin, Mawarni R. 2019. Pengaruh perlakuan jarak tanam dan pemberian pupuk NPK terhadap pertumbuhan dan produksi tanaman jagung (Zea mays L.). Agricultural Research Journal. 15(1): 174-184.

Kabumaini NE, Tjetjep SR. 2010. Jagung Pun Menjadi Agung. Bandung (ID) PT. Puri Delco.

Mayadewi, Ari NN. 2007. Pengaruh Jenis Pupuk Kandang dan Jarak Tanam terhadap Pertumbuhan Gulma dan Hasil Jagung Manis. Agritrop. 26(4): 153-159.

Mimbar, Saubari M. 1990. Pola Pertumbuhan dan Hasil Panen Jagung Hibrida C1 Karena Pengaruh Pupuk N dan Kerapatan Populasi. Agriva. 13(3): 70-82.

Purwono, Hartono R. 2005. Bertanam Jagung Unggul. Jakarta (ID): Penebar Swadaya.

Raharjo D, Nugroho C, Ratule MT. 2013. Kajian Adaptasi Varietas Jagung Komposit Di Konawe Selatan, Sulawesi Tenggara. Dalam: Seminar Nasional Serealia. Page: 67-71.

Rusono N, Sunari A, Muharam A, Avianto N, Martino I, Susilawati, Tejaningsih, Hadi PU. 2014. Rencana Pembangunan Jangka Menengah Nasional Bidang Pangan dan Pertanian 2015-2019. Jakarta (ID): Direktorat Pangan dan Pertanian Bappenas.

Sirappa MP, Razak N. 2010. Peningkatan Produktivitas Jagung melalui Pemberian Pupuk N, P, K dan Pupuk Kandang pada Lahan Kering di Maluku. Dalam: Prosiding Pekan Serealia Nasional. Pusat Penelitian dan Pengembangan Pertanian Kementerian Pertanian. Maros (ID): 27-28 Juli 2010.

Sutejo MM. 1992. Pupuk dan Cara Pemupukan. Jakarta (ID): Bina Aksara.

Tufaila M, Alam S, Leomo S. 2014. Strategi Pengelolaan Lahan Marginal: Ikhtiar Mewujudkan Pertanian yang Berkelanjutan. Kendari (ID): Halu Oleo University Press. 